15. Mazaeva, V. S. O nekotoryh osobennostiah triatsilglitserol'nogo i zhirnokislotnogo sostavov rastitel'nyh masel [Text] / V. S. Mazaeva, I. N. Demidov, N. S. Sytnik, V. A. Golodnyak, V. A. Kishchenko, O. V. Golubets // Nauka I Studia. - 2017. - Vol. 4 (165). P. $102-108$.

16. Bondar, A. G. Planirovanie eksperimenta pri optimizatsii protses sov himicheskoi tehnologii [Text] / A. G. Bondar, G. A. Statiuha, I. A. Potiazhenko. - Kyiv: Vishcha shkola, 1980. - 264 p.

17. Sytnik, N. Effectiveness research of new catalyst for oil and fat interesterification by using chromatographic analysis [Text] N. Sytnik, I. Demidov, E. Kunitsa // Technology Audit and Production Reserves. - 2015. - Vol. 6, No. 4 (26). - P. 8-13. doi:10.15587/2312-8372.2015.53285

18. Identyfikatsiia pereeteryfikovanykh zhyriv. Metodyka vykonannia vymiriuvan [Text]: MVV No. 081/12-0834-12. - Kharkiv: UkrNDIOZh NAAN, 2013. - 37 p.

19. Borovikov, V. P. STATISTICA. Iskusstvo analiza dannyh na komp'iutere dlia professionalov [Text] / V. P. Borovikov. Ed. 2. - St. Petersburg: Piter, 2003. - 688 p.

20. Kudriavtsev, E. M. Mathcad 11: Polnoe rukovodstvo po russkoi versii [Text] / E. M. Kudriavtsev. - Moscow: DMK Press, 2005. - 592 p.

\section{РАСЧЕТ ФИЗИЧЕСКИХ СВОЙСТВ ЖИРОВ ПО ИХ ТРИАЦИЛГЛИЦЕРОЛЬНОМУ СОСТАВУ}

Проведены исследования по получению жировых смесей с заданными свойствами. Определена зависимость между физико-химическими показателями и концентрацией компонен- тов (триацилглицеролов) смеси. Также определен триацилглицерольный (ТАГ) состав переетерифицированых жиров и полученных в ходе эксперимента жировых смесей. Доказано, что существует функциональная зависимость между ТАГ составом и физико-химическими показателями.

Ключевые слова: триацилглицерольный состав, температура плавления, температура застывания, растительное масло.

Mazaeva Viktoria, Junior Researcher, Laboratory for the Study of the Chemistry of Fat Oil-Fat Production, Ukrainian Research Institute of Oils and Fats of the National Academy of Agrarian Sciences of Ukraine, Kharkiv, Ukraine, e-mail: tori-198919@yandex.ua, ORCID: https://orcid.org/0000-0002-5560-9126

Demidov Igor, Doctor of Technical Sciences, Professor, Department of Technology of Fats and Fermentation Products, National Technical University «Kharkiv Polytechnic Institute», Ukraine, e-mail demigon50@ukr.net, ORCID: https://orcid.org/0000-0001-5854-0833

Golodnyak Vladimir, PhD, Consultant on Metrology and Standardization of the Head of the Research Section, National Technical University «Kharkiv Polytechnic Institute», Ukraine, e-mail: gol.saturn@gmail.com, ORCID: https://orcid.org/0000-0002-6501-6666

Onopriyenko Tetyana, PhD, Assistant Professor, Department of Basic and Linguistic Preparation, National Pharmaceutical University, Kharkiv, Ukraine, e-mail: o.tetyana@ukr.net, ORCID: https:// orcid.org/0000-0002-1663-9832

\title{
Palamarek $\mathrm{K}$ INVESTIGATION OF HYDRATION AND FORMATION OF STRUCTURAL-MECHANICAL PROPERTIES OF VEGETABLE PASTE WITH IODINE-CONTAINING RAW MATERIAL
}

Експериментально обгрунтовано технологічні властивості та структурно-механічні характеристики овочевих паст при різних гідромодулях обводнення порошків гідробіонтів та ламінарії. Досліджено вплив тривалості набрякання порошків гідробіонтів та ламінарії на властивості паст. Обгрунтовано вплив конщентращї гідратованих порошків ламінарії та гідробіонтів на структурно-механічні показники овочевих паст. Визначено рачіональний вміст гідратованих порошків з ламінарії та гідробіонтів.

Ключові слова: структурно-механічні характеристики, овочеві пасти, порошки гідробіонтів та ламінаріі, йодовмісна сировина.

\section{Introduction}

To date, the population's nutritional structure has significant deviations from the formula for balanced nutrition, primarily on the level of consumption of vitamins and minerals, including iodine. This causes the formation of risk factors for the development of alimentary and alimentary-dependent diseases.

To prevent diseases caused by iodine deficiency, it is promising to increase its content in food products. This can be done through the integrated use of dietary supplements, food raw materials and functional ingredients in which iodine is in an organically bound state and in conjunction with its synergists. Hydrobionts are a valuable raw material, a reserve of iodine and synergist nutrients, in which iodine is in an organically bound state. An additional source of vitamins of group B, for effective assimilation of iodine, is inactivated yeast, and for tyrosine and calcium - cheese products - bryndza and cottage cheese. Vegetable raw material balances the taste, improves the nutritional and biological value of the product. So, the complex use of this raw material in the food composition will create a food product with sufficient iodine content in the form associated with organic compounds and other iodine synergists with functional and technological properties. 
In connection with the foregoing, it is important to create a new culinary product with an increased content of bio-available iodine by developing technologies for vegetable pastes that involve the use of iodine-containing raw materials and other physiologically functional ingredients with certain biologically functional properties.

Scientific substantiation, development and introduction of the newest technologies of culinary products with the use of raw materials of natural origin is relevant and will promote the implementation of the national program «Health 2020: Ukrainian Dimension» for 2012-2020 [1].

\section{The object of research and its technological audit}

The object of research is the technology of vegetable pastes with iodine-containing raw materials.

For the mathematical modeling of food compositions (Fig. 1), the content of micronutrient concentrates and ingredients in the finished product has been limited (taking into account previous technological developments, the requirements of regulatory documentation).

It is established that the milk protein after consumption forms the amino acids necessary for the binding of iodine. In this regard, as a basis for plant-protein structured product, it has been proposed to use protein-contained products as a part of food compositions (Fig. 1), which will enrich them with effective iodine-protein bonds.

The quantity of powders made from hydrobionts for introduction into food compositions is limited, after all according to the experiments the increase in the content of raw materials negatively affects the organoleptic characteristics of ready meals.

The technological process of preparation of vegetable pastes with iodine-containing raw materials is accompanied by physicochemical and mechanical processes that affect their rheological characteristics. Physicochemical parameters of pastes depend on raw materials, added additives and process parameters. Rheological properties are characterized by effective limiting shear stress and adhesion.

One of the most problematic places is the cost of iodine-containing raw materials, namely, powders made from hydrobionts. Comparison of the price of powders made from hydrobionts with the price of traditional raw materials shows that they are not competitive enough, because they exceed the traditional one.

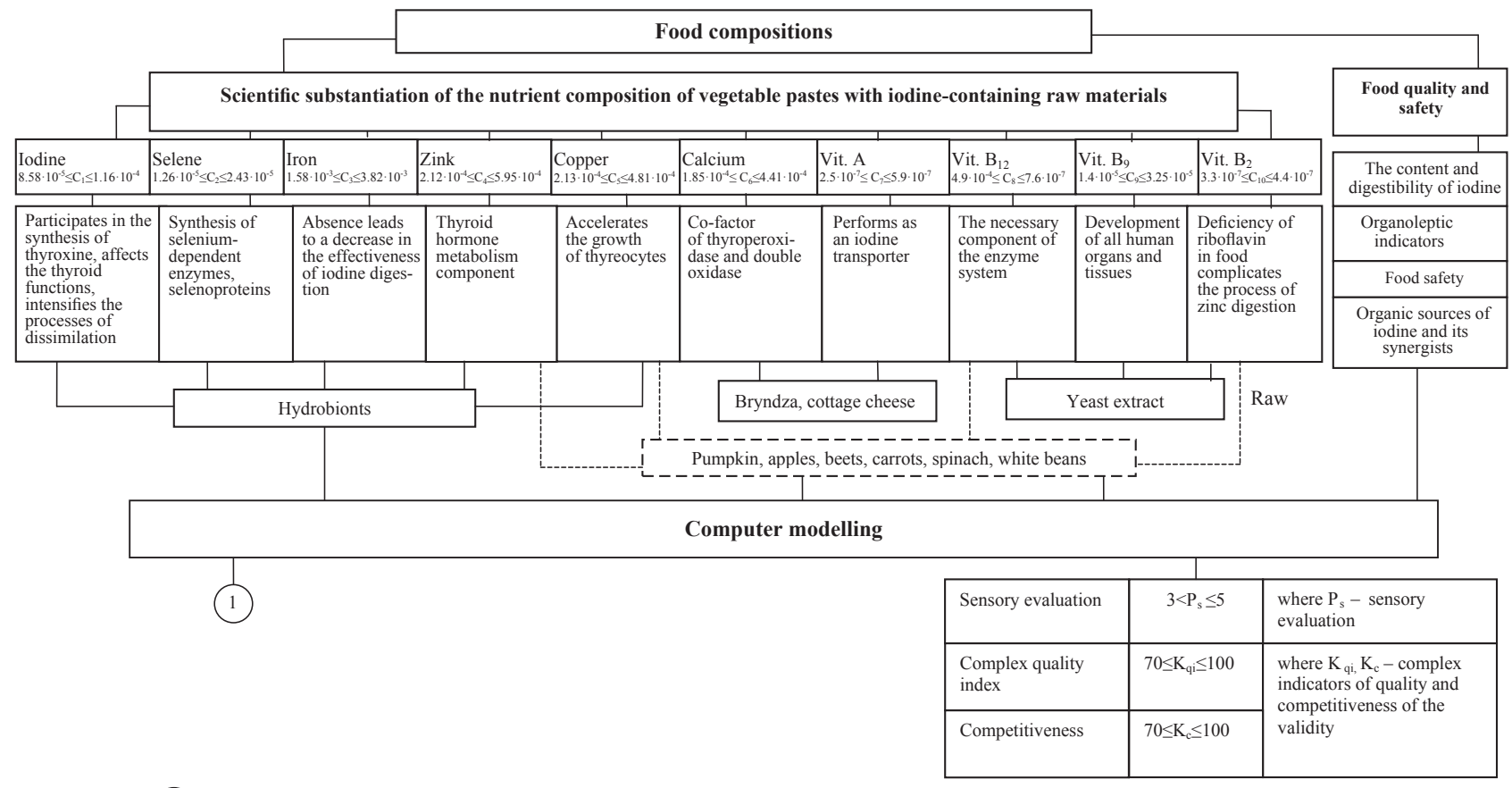

\begin{tabular}{|c|c|c|c|c|c|}
\hline \multirow[b]{2}{*}{$\begin{array}{l}\text { Name of recipe } \\
\text { ingredients }\end{array}$} & \multicolumn{4}{|c|}{ Mass fraction of components, $\mathrm{kg}$} & \multirow{10}{*}{$\begin{array}{c}\text { Limitations on } \\
\text { the content of } \\
\text { ingredients, } \\
\text { where Y1, Y2, } \\
\text { Y3, Y4, Y5, Y6, } \\
\text { Y7, Y8, Y9, Y10, } \\
\text { Y11, Y12 - mass } \\
\text { fractions (\%) of } \\
\text { the corresponding } \\
\text { ingredients in the } \\
\text { semi-finished } \\
\text { product }\end{array}$} \\
\hline & $\begin{array}{c}\text { Pumpkin-apple- } \\
\text { cheese pasta } \\
\text { with shrimp } \\
\text { powder }\end{array}$ & $\begin{array}{l}\text { Carrot-beet-cheese } \\
\text { paste with } \\
\text { pollack powder }\end{array}$ & $\begin{array}{l}\text { Spinach-carrot- } \\
\text { beet-pumpkin } \\
\text { paste with crab } \\
\text { powder }\end{array}$ & $\begin{array}{l}\text { Carrot-beet-apple } \\
\text { bean paste with } \\
\text { cod powder }\end{array}$ & \\
\hline $\begin{array}{l}\text { Hydrated powder made } \\
\text { from laminaria }\end{array}$ & $2,5 \leq \mathrm{Y}_{1} \leq 3,5$ & $2,5 \leq \mathrm{Y}_{1} \leq 3,5$ & $2,5 \leq \mathrm{Y}_{1} \leq 3,5$ & $2,5 \leq \mathrm{Y}_{1} \leq 3,5$ & \\
\hline $\begin{array}{l}\text { Hydrated powder made } \\
\text { from hydrobionts }\end{array}$ & $47,5 \leq Y_{2} \leq 48,5$ & $47,5 \leq Y_{2} \leq 48,5$ & $47,5 \leq Y_{2} \leq 48,5$ & $47,5 \leq Y_{2} \leq 48,5$ & \\
\hline Pumpkin-apple puree & $32,5 \leq Y_{3} \leq 33,5$ & - & - & - & \\
\hline Carrot-beet puree & - & $32,5 \leq \mathrm{Y}_{3} \leq 33,5$ & - & - & \\
\hline $\begin{array}{l}\text { Spinach-carrot-beet- } \\
\text { pumpkin puree }\end{array}$ & - & - & $40,5 \leq Y_{3} \leq 41,5$ & - & \\
\hline Carrot-beet-apple-bean puree & - & - & - & $40,5 \leq Y_{3} \leq 41,5$ & \\
\hline Bryndza & $7,5 \leq Y_{4} \leq 8,5$ & $7,5 \leq Y_{4} \leq 8,5$ & $7,5 \leq \mathrm{Y}_{4} \leq 8,5$ & $7,5 \leq Y_{4} \leq 8,5$ & \\
\hline Cottage cheese & $7,5 \leq Y_{5} \leq 8,5$ & $7,5 \leq Y_{5} \leq 8,5$ & - & - & \\
\hline Total & 100 & 100 & 100 & 100 & \\
\hline
\end{tabular}

Fig. 1. Block diagram of modeling the nutrient composition of food compositions 


\section{The aim and objectives of research}

The aim of research is hydration and formation of structural and mechanical properties of vegetable pastes with iodine-containing raw materials.

To achieve this aim, it is necessary to perform the following tasks:

1. To experimentally substantiate the technological properties and structural and mechanical characteristics of vegetable pastes for various hydromodules of watering powders of hydrobionts and laminaria.

2. To investigate the effect of the swelling duration of powders of hydrobionts and laminaria on the properties of pastes.

3. To substantiate the effect of the concentration of hydrated laminaria powders and hydrobionts on the structural and mechanical characteristics of vegetable pastes.

4. To determine the rational content of hydrated powders made from laminaria and hydrobionts.

\section{Research of existing solutions of the problem}

World practice shows that, in addition to mass iodization of salt, there is also enrichment with iodine of many food products and raw materials. Despite the existence of various iodine products on the market, iodine deficiency exists.

Among the main ways to overcome iodine deficiency in nutrition are methods of individual, group and mass iodine prophylaxis [1-3].

By mass iodine prophylaxis, it is considered one of the productive and economic methods to overcome iodine deficiency. This method is achieved by adding salts of iodine (iodide and potassium iodate) and food biologically active substances that contain iodine in organic form, into the most common foods: bread, salt, water. This method of prevention is called «dumb» - the consumer may not know that he consumes food products enriched with iodine [4].

In India, the main direction of the National Iodine Deficiency Disorders Control Program (NIDDCP) is the enrichment of the total salt with potassium iodide [5].

According to the monitoring of 11-15 year old iodine prophylaxis of hypothyroidism with iodized salt or iodine tablets, an increase in hyperthyroidism is observed in the USA, Australia, and Germany [6]. For the same reason, in Denmark, the sale of iodized salt is limited [7].

Numerous works of scientists confirm that in some diseases the use of table salt is contraindicated, therefore, for a certain population category the above sources of iodine are unacceptable [8, 9]. Consumption of iodized salt in certain categories of the population can cause hyperthyroidism. This is due to the fact that the daily requirement for iodine provides consumption of $3-5$ grams of iodized salt, and practical experience shows that most people tend to use excess salt [10].

In hydrobionts the greatest content of iodine is observed, whereas in terrestrial foodstuffs it is small. Therefore, worldwide searches and technological development of creation of special iodine-containing products are conducted.

During the patent search and review of analytical literature, information was found on the development of iodized oils, dairy products, processed cheeses, flour, yeast, confectionery and meat products [7, 11, 12].
The drawbacks of the known methods are that iodine in them is found as a component of a mechanical mixture, and not in a bound state with the components of the product. And the inclusion of iodine in a nutrient medium for growth of yeast can change their metabolism.

Leading scientists have developed:

- technological regulations for obtaining a new type of milk protein paste «Morska», enriched with iodine and other minerals contained in laminaria, as well as the essential amino acids of whey proteins. Regularities in the formation of a combined milk protein product for prophylactic use based on cottage cheese with the addition of sea cabbage [13];

- technology of iodized boiled sausage «Rasskazovskaya Novaya». To prepare boiled sausage, a proteinfat emulsion of isolated soy protein was used, which was dissolved in a solution of potassium iodide. It is proved that the use of protein-fat emulsion enriched with iodine reduces the production cycle for 24 hours, improves the consistency and increases the yield of the finished product by $4-5 \%$. At the same time, daily human needs for iodine are provided by $23-25 \%$ [14]; - the following recipes for culinary products and technologies for their production based on sea kale: salads «Sea Tropics», «Triton», «Samurai» and «Duo». The influence of the new added ingredients on the improvement of lipid, microbiological, organoleptic characteristics of the products has been substantiated and experimentally proved. Under the influence of antiseptic properties of wasabi and citric acid, during the storage, the microbial spoilage of the product, the stabilization of the process of hydrolysis and oxidation of lipids, the hydrolysis of proteins, and, as a consequence, the preservation of the gustatory characteristics of the initial product [15];

- technology of introducing potassium iodide into the dough during the bread production. This study indicates that the loss of iodine during bread iodization with potassium iodide is at least $60 \%$ [16].

Taking into account the above, it can be concluded that a large range of iodized culinary products has been developed, but for better assimilation of iodine, the body needs to take it in conjunction with synergists, not taken into account by the developers in the above mentioned culinary products.

\section{Methods of research}

Investigation of structural and mechanical properties of vegetable pastes with iodine-containing raw materials was carried out at the measuring complex «Physical Laboratory of ITM» (Ukraine), with a force sensor of a digital dynamometer with a division price of $0.5 \mathrm{mN}$ and an upper limit of $3 \mathrm{~N}$. The measurement period is $0.05 \mathrm{~s}$. The measurement data is output in the form of a graph in the coordinates «force/time».

Adhesion is determined by tearing off a polished disk made from a nickel-iron alloy with a diameter of $20 \mathrm{~mm}$. A dynamometer with a fixed stainless steel disk without holes is lowered to the horizontal section of the product. The disk is pressed into the product by $0.5-1.0 \mathrm{~mm}$, while the force value lies outside the measuring limit of the dynamometer. After 2-3 seconds of pressing, the dynamometer with the disk is slowly raised and the force value is recorded every $0.05 \mathrm{~s}$. 
The maximum value of the force divided by the area of contact of the adhesive with the substrate will be equal to the adhesion of the product, which is determined by the formula:

$$
\omega_{a}=-\frac{4\left(F_{p}-P_{a d d}\right)}{\pi d^{2}},
$$

where $F_{p}$ - the peak value of the force when disc is detached, $\mathrm{mN} ; d$ - diameter of the disc $(21.7 \mathrm{~mm}) ; \pi-3.14$; $P_{a d d}$ - additional (uncompensated) values of the weight of the indenter, $\mathrm{mN}$ [17].

Measurement of the ultimate shear stress is carried out using a load cell with a measuring range of $0.001-50 \mathrm{~N}$, division value of dynamometer is $0.000313 \mathrm{~N}$, the absolute error of a single measurement is no more than $\pm 0.000014 \mathrm{~N}$. The measurement period is $50 \mathrm{~ms}$. The measurement data is output in the form of a graph in the coordinates «force/time».

Two parallel plates with a width $(b)$ of $17.5 \mathrm{~mm}$, a thickness $(d)$ of $0.3 \mathrm{~mm}$ and a height (depth of immersion) of $15 \mathrm{~mm}$, as well as a distance between the plates of $7.4 \mathrm{~mm}$, are lowered into the test sample. On the maximum value of the force $(F)$, when stretching the plates, determine the ultimate shear stress $(\theta)$. The displacement velocity is determined from the analysis of the graphs (0.002 min - stretching time of the sample, s).

The ultimate shear stress (USS) versus the shear rate is determined by the formula:

$$
\theta_{s t}=\frac{F_{p}-P_{a d d}}{4 b h},
$$

where $F_{p}$ - the peak value of the force when stretching the indenter (plane-parallel plates), $\mathrm{mN} ; P_{a d d}-$ additional (uncompensated) values of the weight of the indenter, $\mathrm{mN}$. The weight of the indenter is compensated by special settings on the universal measuring computer device, however it is too difficult to compensate for the weight within $\pm 15 \mathrm{mN}$. In addition, the weight of product residues on the indenter has a significant influence on such accurate value, which changes after each experiment; $b$ - the width of plates (average value), $\mathrm{mm} ; h$ - the depth of immersion of the plates (mean value), mm [18].

The moisture retention capacity (MRC) is defined as the difference between the mass fraction of moisture in the product and the amount of moisture removed during the heat treatment [19]. The sample of minced meat $4 \ldots 6 \mathrm{~g}$ is uniformly applied with a glass rod to the inner surface of a wide part of the milk fat-and-salt, closed with a stopper and heated in a water bath at a temperature of $100{ }^{\circ} \mathrm{C}$ for $15 \cdot 60 \mathrm{~s}$.

The moisture retention capacity is determined by the formula (\%):

$$
\begin{aligned}
& M R C=M-M B C, \\
& M B C=a n m^{-1} 100,
\end{aligned}
$$

where $M$ - the total mass fraction of moisture in the sample, \%; $M B C$ - the amount of moisture removed during the heat treatment, \%; $a$ - diviion value of the oleometer, $a=0.01 \mathrm{~cm}^{3} ; n-$ the number of divisions on the oleometer scale; $m$ - weight of the sample, $g$.
As a result of the preliminary analysis [20], it is determined the expediency of the joint use of vegetable and protein ingredients, as well as inactivated yeast in the vegetable pastes that will ensure the high biological value of the product and a high level of iodine assimilation.

To create the technology of vegetable pastes, the use of pumpkin-apple, carrot-beet, spinach-carrot-beet-pumpkin, carrot-beet-apple-bean purees as the main component, and iodine-containing raw materials (hydrated laminaria and hydrobiont powders), bryndza and cottage cheese - as an additional.

The design of vegetable pastes with iodine-containing raw materials must be carried out taking into account the realization of their technological and organoleptic properties, by introducing the recipe ingredients in the vegetable pastes.

Vegetable paste of functional purpose is used as a control [21].

Previous studies have found that the introduction of hydrobiont and laminaria powders does not allow the production of pastes of a uniform consistency. Due to the large hygroscopicity of the hydrobiont and laminaria powders, lumps immediately form which, even with prolonged stirring, are unevenly distributed over the paste mass.

As a result of the carried out studies [22], the dependence of the technological and structural-mechanical properties of hydrobiont and laminaria powders on the hydromodule and the swelling duration is established. In this regard, the powders of hydrobionts and laminaria are watered with a hydromodule from 1:1 to $1: 7$.

\section{Research results}

Studies have shown that when water is applied to the hydromodule 1:4, the product had an insufficiently watered, inhomogeneous consistency with the inclusion of dry lumps. Increasing the hydromodule more than 1:7 leads to the separation of water and the production of an excessively fluid consistency. Fig. 2 shows the research results of the effect of laminaria powder hydromodule on inactivated yeast and hydrobiont powder on water on the technological properties of pastes.

It is established (Fig. 2) that the use:

- laminaria powder with the hydromodule from 1:4

to 1:5 leads to an increase in the moisture binding capacity (MBC) of pastes by 1.6...2.2 \% and further reduction to the value of $94.3 \%$ with the hydromodule $1: 7$

- hydrobionts powder to water with the hydromodule from 1:5 to 1:6 leads to an increase in the MBC index of pastes by 3.3...4.2\% and further decrease to a value of $72.3 \%$ with the hydromodule $1: 7$

The indicator of pastes $M R C$ hydrobiont and laminaria powders with the hydromodule from $1: 6$ to $1: 7$ and with the hydromodule from 1:4 and 1:7, respectively, practically does not differ from the control. In this case, the use of laminaria powder with the hydromodule from 1:4 to $1: 5$ and the use of hydrobiont powder with the hydromodule from $1: 5$ to $1: 6$ leads to an increase in this index by $1.7 \ldots 2.8 \%$ and $2.7 \ldots 3.9 \%$, respectively.

Fig. 3 shows the research results of the effect of a hydromodule of hydrobiont powder on water and laminaria powder in inactivated yeast on the structural and mechanical characteristics of pastes. 


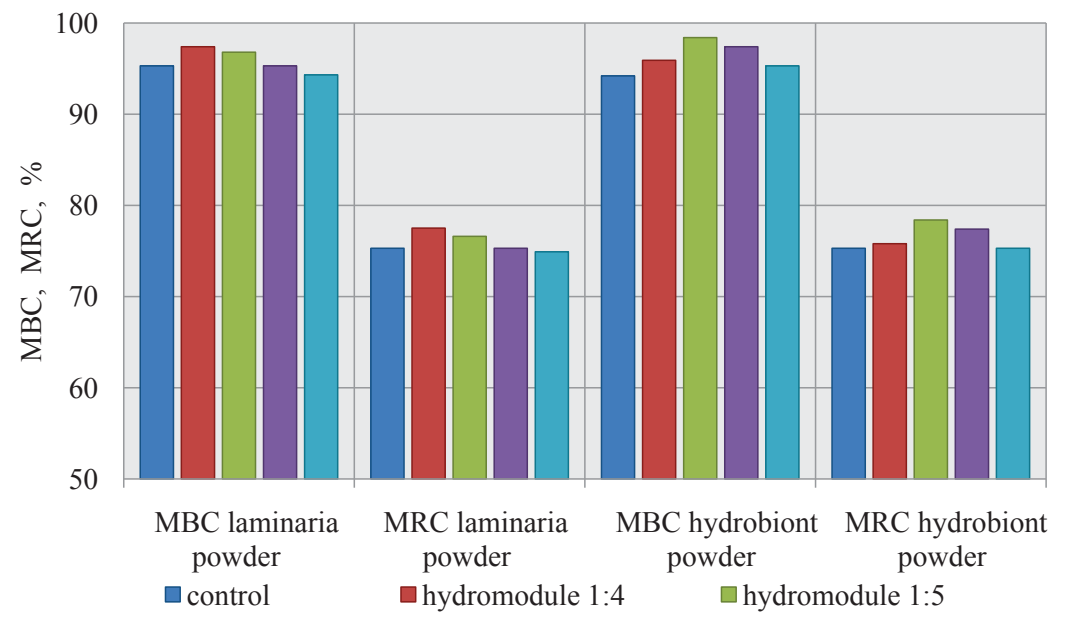

Fig. 2. Technological properties of vegetable pastes at various hydromodules of watering hydrobionts and laminaria powders

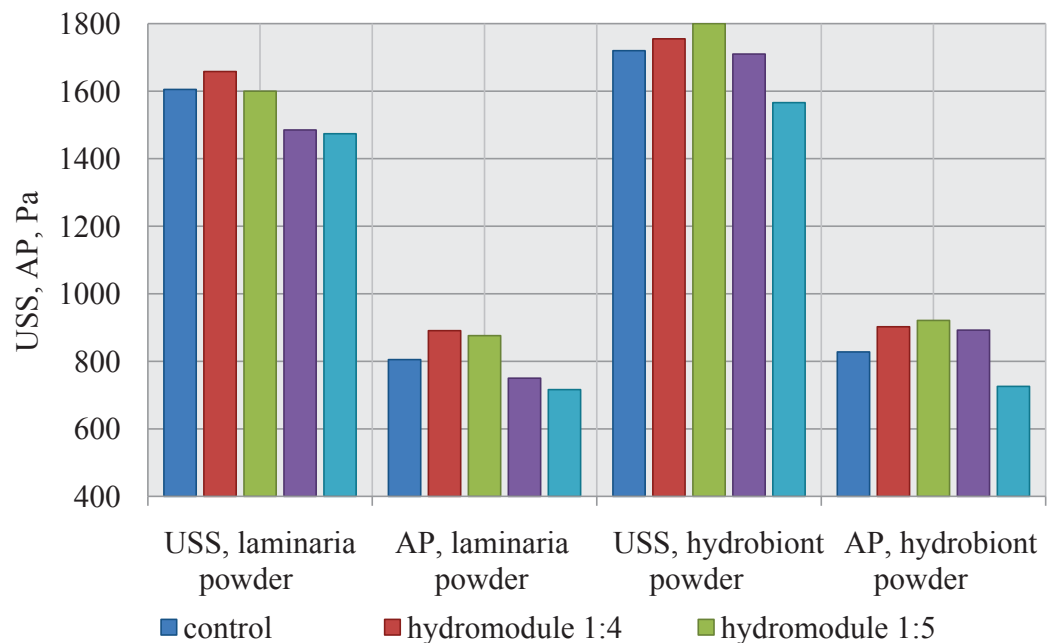

Fig. 3. Structural and mechanical characteristics of vegetable paste with various hydromodules for watering hydrobiont and laminaria powders

Research results show that an increase in the hydromodule of laminaria powder in inactivated yeast and hydrobiont powder to water more than 1:4 and 1:5, respectively, leads to a decrease in the values of structural and mechanical characteristics of the pastes. So, with the increase of the hydromodule of laminaria powder in inactivated yeast from $1: 4$ to $1: 7$, the reduction of the limiting shear stress by $3.5-11.1 \%$, respectively the adhesive property (AP) by $1.6 . .19 .6 \%$. When the hydromodule powder of hydrobionts increased to water, from 1:5 to $1: 7$, the shear stress is reduced by $5-13 \%$, respectively, the adhesion property is $3.1 \ldots 21.2 \%$, which is due to the weakening of the bonds between the paste components.

Further, the influence of the swelling duration of hydrobiont and laminaria powders on the properties of pastes is studied. For the study, vegetable pastes are used, in which hydrobiont and laminaria powders are used, watered with the hydromodule 1:4 and 1:5, respectively. The swelling duration of hydrobiont and laminaria powders ranges from 0 to $9 \cdot 10^{2} \mathrm{~s}$.

Table 1 shows the research results of the influence of the swelling duration of hydrobiont powder and laminaria for the technological properties of vegetable pastes.

It has been established that an increase in the swelling time of laminaria powder leads to an increase in the MBC index of pastes by $2.2-3.3 \%$ and hydrobiont powder by 2.7-4.8\%, and for MRC by $2.8-3.8 \%$ and $6.2-7.3 \%$ respectively. At the same time, the highest technological parameters are pasta with laminaria powder, which swells for $6 \cdot 10^{2} \mathrm{~s}$ and with hydrobiont powder - for $9 \cdot 10^{2} \mathrm{~s}$. Further increase in the swelling duration of hydrobiont and laminaria powders has virtually no effect on these parameters.

Table 1

Influence of the swelling duration of hydrobiont and laminaria powders on the technological properties of vegetable pastes

\begin{tabular}{|c|c|c|}
\hline Sample & $\begin{array}{c}\text { MBC, } \\
\%\end{array}$ & $\begin{array}{c}\text { MRL, } \\
\%\end{array}$ \\
\hline Control (vegetable paste of a functional purpose) & 95.3 & 72.3 \\
\hline Sample No. 1 (without swelling of laminaria powder) & 97.4 & 74.3 \\
\hline Sample No. 2 (swelling time of laminaria powder $3 \cdot 10^{2} \mathrm{~s}$ ) & 97.9 & 74.8 \\
\hline Sample No. 3 (swelling time of laminaria powder $6 \cdot 10^{2} \mathrm{~s}$ ) & 98.4 & 75.1 \\
\hline Sample No. 4 (swelling time of laminaria powder $9.10^{2}$ s) & 98.4 & 75.1 \\
\hline Sample No. 1 (swelling time of hydrobiont powder) & 97.9 & 76.8 \\
\hline Sample No. 2 (swelling time of hydrobiont powder $3 \cdot 10^{2} \mathrm{~s}$ ) & 99.5 & 77.3 \\
\hline Sample No. 3 (swelling time of hydrobiont powder $6 \cdot 10^{2} \mathrm{~s}$ ) & 98.9 & 78.6 \\
\hline Sample No. 4 (swelling time of the hydrobiont powder $9.10^{2}$ s) & 99.9 & 77.6 \\
\hline
\end{tabular}


It is established (Table 2), the AP indicator of pastes increases depending on the variable factors. The minimum peel force $(811 \mathrm{~Pa})$ is noted in the control.

Table 2

Influence of the swelling duration of hydrobiont and laminaria powders on the structural and mechanical characteristics of vegetable pastes

\begin{tabular}{|c|c|c|}
\hline Sample & \begin{tabular}{|c} 
US5, \\
$\mathrm{Pa}$
\end{tabular} & $\begin{array}{c}\mathrm{AP}, \\
\mathrm{Pa} \\
\end{array}$ \\
\hline Control (vegetable paste of a functional purpose) & 1555 & 811 \\
\hline Sample No. 1 (without swelling of laminaria powder) & 1605 & 869 \\
\hline Sample No. 2 (swelling time of laminaria powder $3 \cdot 10^{2}$ s) & 1615 & 891 \\
\hline Sample No. 3 (swelling time of laminaria powder 6.10 s) & 1658 & 897 \\
\hline Sample No. 4 (swelling time of laminaria powder 9.10² s) & 1660 & 900 \\
\hline Sample No. 1 (swelling time of hydrobiont powder) & 1607 & 871 \\
\hline Sample No. 2 (swelling time of hydrobiont powder $3 \cdot 10^{2} \mathrm{~s}$ ) & 1617 & 893 \\
\hline Sample No. 3 (swelling time of hydrobiont powder $6 \cdot 10^{2} \mathrm{~s}$ ) & 1640 & 899 \\
\hline Sample No. 4 (swelling time of the hydrobiont powder $9 \cdot 10^{2}$ s) & 1660 & 900 \\
\hline
\end{tabular}

The increase in the swelling duration of the hydrobiont and laminar powders leads to an increase in the contact surface of the paste and the «structure meter» plate and indicates an increase in the intermolecular interaction (bonding forces) at the interface. At the same time, an increase in the AP of laminaria powder by $7.1-10.9 \%$ and hydrobiont powder by $7.4-10.9 \%$ is noted, which indicates an increase in the stickiness of the paste, improving the stability of the paste during the formation and transportation.

As a result of the conducted researches, it is established that samples of vegetable pastes with laminaria powder with hydromodule 1:4 and hydrobiont powder with hydromodule 1:5, which flow for $6 \cdot 10^{2} \mathrm{~s}$ and $9 \cdot 10^{2} \mathrm{~s}$, respectively, have the highest technological parameters.

When determining the rational amount of hydrated powders made from hydrobionts and laminaria, attention is paid to changes in structural-mechanical and organoleptic characteristics (Table 3, Fig. 4).

Table 3

Characteristics of samples depending on the concentration of powders

\begin{tabular}{|c|c|c|c|c|c|}
\hline $\begin{array}{c}\text { Sam- } \\
\text { ples }\end{array}$ & $\begin{array}{c}\text { Hydrobionts } \\
\text { content, \% }\end{array}$ & $\begin{array}{c}\text { Laminaria } \\
\text { content, \% }\end{array}$ & $\begin{array}{c}\text { Sam- } \\
\text { ples }\end{array}$ & $\begin{array}{c}\text { Hydrobionts } \\
\text { content, \% }\end{array}$ & $\begin{array}{c}\text { Laminaria } \\
\text { content, \% }\end{array}$ \\
\hline 1 & 16 & 1 & 4 & 40 & 2.5 \\
\hline 2 & 24 & 1.5 & 5 & 48 & 3 \\
\hline 3 & 32 & 2 & 6 & 56 & 3.5 \\
\hline
\end{tabular}

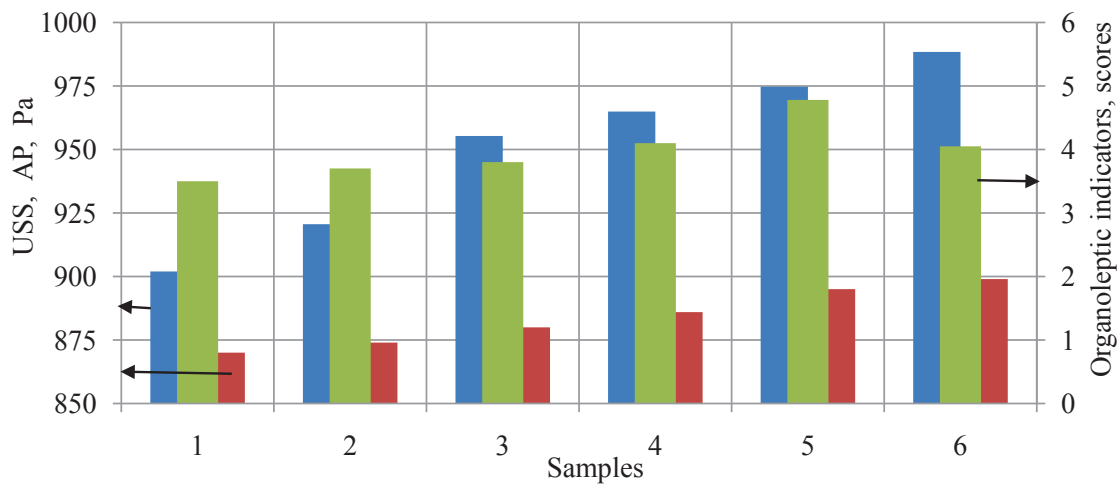

Fig. 4. Influence of the concentration of hydrated laminaria and hydrobiont powders on the structural and mechanical characteristics of vegetable pastes: - - ultimate shear stress (US5), $\mathrm{Pa}$; - adhesion property (AP), $\mathrm{Pa}$; - organoleptic indicators, scores
It is established that the structural-mechanical and organoleptic parameters of pastes vary depending on the concentration of powders. The minimum tearing force is $870 \mathrm{~Pa}$, an organoleptic score is 3.5 points and USS is $1506.00 \mathrm{~Pa}$ are noted in pastes with a concentration of hydrated laminaria powders and hydrobionts of $16 \mathrm{~g}$ and $1 \mathrm{~g}$ respectively (Fig. 4). An increase in the concentration of powders leads to an increase in the contact surface of the paste and the plate of the «structure meter» and indicates an increase in the intermolecular interaction (bonding forces) at the interface, and is marked by an increase in organoleptic parameters. At the same time, the growth of the $\mathrm{AB}$ pastes index at a concentration of hydrated laminaria powder $3 \mathrm{~g}$ and hydrated hydrobiont powder $48 \mathrm{~g}$ by $2.8 \%$, as well as the growth of the organoleptic index to the highest value of 4.78 points are noted. This indicates an increase in the stickiness of the paste, improving the stability of the paste during the formation and transport.

For a more accurate determination of the rational amount of hydrated hydrobiont and laminaria powder, a mathematical method is used, where as a criterion of optimization a complex quality index $\left(C_{q i}\right)$ is adopted. This index covers the following properties: organoleptic evaluation, content of iodine synergists and physicochemical parameters (ultimate shear stress, adhesion).

By mathematical processing of the experimental data, regression equations describing the single-factor space of the $C_{q i}$ dependence on the concentration of hydrated powders made from hydrobionts and laminaria in vegetable pastes are determined (Fig. 5, 6).

So an increase in the content of hydrated laminaria more than $3 \%$ and hydrated powders made from hydrobionts more than $48 \%$ worsened the taste, smell and consistency of the paste. The graphical dependence of the complex quality index on the concentration of hydrated laminaria powders and hydrobionts is graphically depicted in Fig. 5, 6.

The relationship between the concentration of hydrated powder made from hydrobionts and the complex quality index is described by the following equation:

$$
Y=-0.0194 x^{2}+1.8638 x+42.45 \text {, }
$$

where $x$ - concentration of hydrated powder made from hydrobionts, $\%$; $Y$ - complex indicator of the quality of pastes, units.

Hence let's determine the extremum point of this function:

$$
\begin{aligned}
& \max \left\{\begin{array}{l}
-0.0194 x^{2}+ \\
+1.8638 x+42.45
\end{array}\right\}= \\
& =\frac{169196761}{1940000} \text { at } x=\frac{9319}{194}, \\
& Y(\max )=48.03 .
\end{aligned}
$$

The relationship between the concentration of hydrated laminaria powder and the complex quality index is described by the following equation:

$$
\begin{aligned}
& Y=-3.5711 x^{2}+21.783 x+ \\
& +60.517,
\end{aligned}
$$


where $x$ - concentration of hydrated powder made from laminaria, \%; $Y$ - complex indicator of the quality of pastes, units.

Hence let's determine the extremum point of this function:

$$
\begin{aligned}
& \max \{=-3.5711 x 2+21.783 x+60.517\}=\frac{6694740619}{71422000} \\
& \text { at } x=\frac{108915}{35711}, Y(\max )=3.04 .
\end{aligned}
$$

So, the rational content of hydrated laminaria is $3.0 \%$ and hydrated powders made from hydrobionts $-48 \%$.

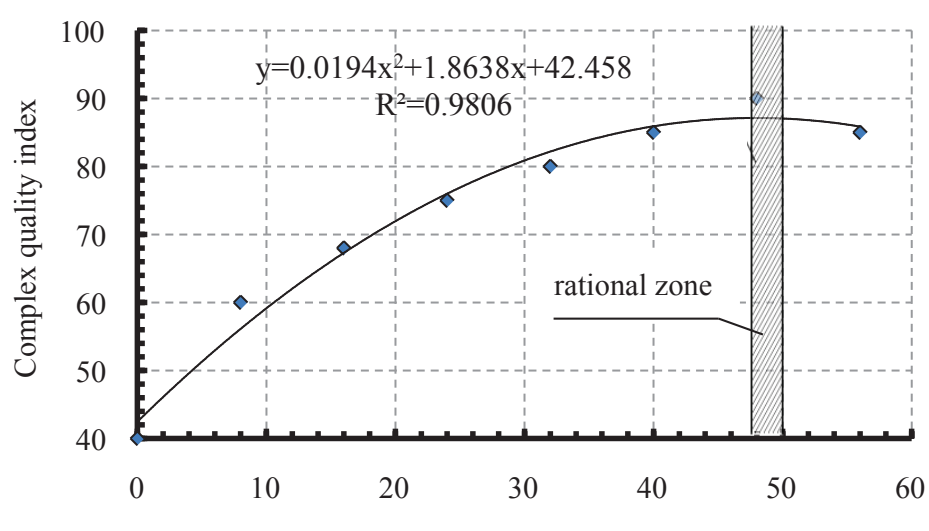

Concentration of hydrated powder made from hydrobionts, $\%$

Fig. 5. Rational content of hydrated powder made from hydrobionts

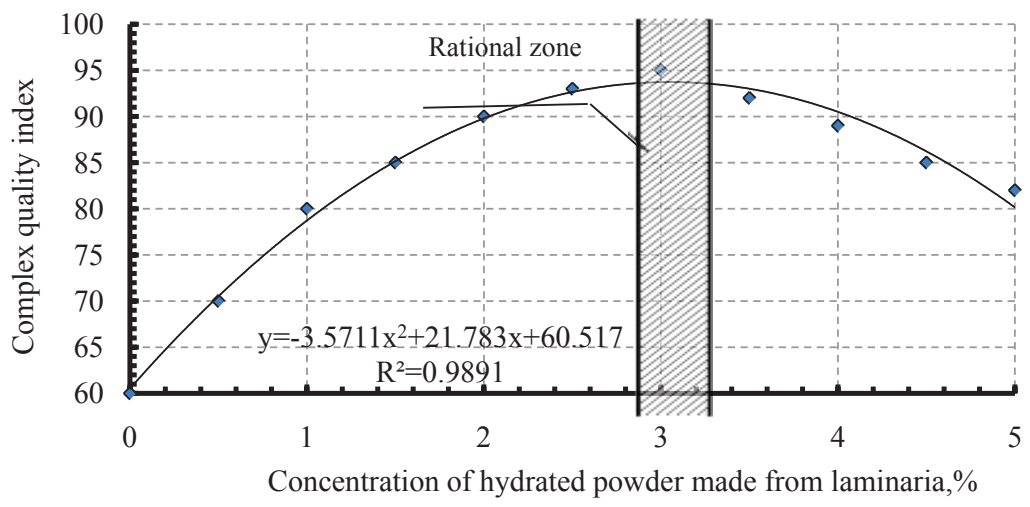

Fig. 6. Rational content of hydrated powder made from laminaria its synergists, and have rheological properties optimal for pasty masses.

The conducted researches allows to develop the formulation composition and technological process of obtaining rolls with vegetable paste made from iodine-containing raw materials, which is fixed in the approved technical conditions: TU U 10.8-05476322-002:2013 «Culinary products. Rolls with vegetable fillings» and technological instruction with TU U 15.8-32214657-003:2010 «Culinary products. Rolls with vegetable fillings».

Weaknesses. As noted above, the use of dry powders made from hydrobionts in the production of paste-like combined products will increase the cost of the product.

Opportunities. But the use of dry powders will also make it possible to simplify and simplify the technology of cooking as much as possible while improving the organoleptic and improving the physicochemical performance of finished products. Since a high moisture content in hydrobionts is the cause of their instability during storage, due to bacterial, enzymatic and chemical damage.

The consistency of the developed vegetable pastes makes it possible to use them for making sandwiches, decorating banquet cold starters, like minced meat and stuffing for curd, potato rolls, flour products, etc.

In the process of carrying out the research, it was found that the social effect of implementing the research into practice is as follows:

- expansion of the range of culinary products with high iodine content and balanced nutrient composition;

- increase of food value of culinary products;

- prevention of endemic diseases;

- increase of productivity, improvement of working conditions and culture of production in restaurants.

Threats. The practical use of the developed products has revealed the need to calculate economic indicators, which confirm the economic efficiency from the introduction of the developed products.

As a research result, the concentration of hydrated powders made from hydrobionts and laminaria is established, making it possible to obtain vegetable pastes with iodine-containing raw materials with functional and technological properties.

\section{SWOT analysis of research results}

Strengths. Based on a series of previous studies and taking into account the data, the ingredients of vegetable pastes with an increased content of iodine and nutrientssynergists based on the use of protein and vegetable raw materials are justified and developed.

The aim of rheological research is the design of vegetable paste formulations with iodine-containing raw materials with given organoleptic parameters that maximally satisfy the requirements of a balanced composition of iodine and
Therefore, comparing the price of vegetable pastes with the price of traditional products shows that it is not competitive enough, because it exceeds the traditional one. However, when determining the competitiveness of new products, one should take into account that they have higher quality characteristics

\section{Conclusions}

1. The technological properties and structural and mechanical characteristics of vegetable pastes for various hydromodules of watering hydrobiont and laminaria powders are experimentally proved. The use of laminaria powder with the hydromodule from 1:4 to 1:5 and the use of hydrobiont powder with the hydromodule from 1:5 to 1:6 leads to an increase in the technological properties of vegetable pastes by $1.7 \ldots 2.8 \%$ and $2.7 \ldots 3.9 \%$, respectively. 
2. It is revealed that an increase in the swelling duration of powders of hydrobionts and laminaria leads to an increase in the strength properties of the test paste. This is confirmed by an increase in the USS index of $3.2-6.7 \%$ and $3.3-6.7 \%$, respectively, compared with the control and indicates the formation of an elastic-viscous structure.

3. It is shown that the structural and mechanical parameters of vegetable pastes increase with a concentration of hydrated laminaria powder $3 \mathrm{~g}$ and hydrated hydrobiont powder $48 \mathrm{~g}$ by $2.8 \%$, and the organoleptic index increases to the highest value of 4.78 points. This indicates an increase in the stickiness of the paste, improving the stability of the paste during the formation and transport.

4. It is established that the rational content of hydrated powders made from laminaria and hydrobionts is 3 and $48 \%$, respectively.

\section{References}

1. Pro skhvalennia kontseptsii zahalnoderzhavnoi prohramy «Zdorovia 2020: ukrainskyi vymir» [Electronic resource]: Order of the Cabinet of Ministers of Ukraine from October 31, 2011 No. 1164-p. - Available at: \www/URL: http://zakon5.rada. gov.ua/laws/show/1164-2011-p

2. Antsiferov, M. B. Organizatsiia osnovnyh meropriiatii po profilaktike zabolevanii, obuslovlennyh defitsitom ioda [Text] / M. B. Antsiferov, N. Yu. Sviridenko, N. H. Filatov // Klinicheskaia tireoidologiia. - 2004. - Vol. 2, No. 2. - P. 18-21

3. Sviridenko, N. Yu. Ioddefitsitnye zabolevaniia. Epidemiologiia, metody diagnostiki, profilaktiki i lecheniia [Text]: Thesis of the Doctor of Medical Sciences: 14.00 .03 / N. Yu. Sviridenko. Moscow, 1999. - 264 p.

4. Tronko, N. D. Kakie metody iodnoi profilaktiki naibolee predpochtitel'ny? [Text] / N. D. Tronko, G. A. Gerasimov, V. I. Kravchenko // Vse, chto vy hoteli by znat' o iododefitsitnyh zabolevaniiah i iodirovannoi soli. - Kyiv, 2004. - P. 29-30.

5. Teas, J. Iodine in dietary seeweeds: metabolism and possible Public Health Concezns [Text] / J. Teas, A. Critchley, S. Pino, L. Braverman // XVII International Seaweed Symposium, January 28 - February 2, 2001. - Cape Town, South Africa, 2001. - $181 \mathrm{p}$.

6. Burgi, H. The Toxicology of Iodate: A Review of the Literature [Text] / H. Burgi, T. Schaffner, J. P. Seiler // Thyroid. - 2001. Vol. 11, No. 5. - P. 449-456. doi:10.1089/105072501300176408

7. Shchepliagina, L. A. V XX veke bez iodnogo defitsita. Programma deistvii dlia pravitel'stvennyh i nepravitel'stvennyh organizatsii [Text] / L. A. Shchepliagina // Zdorov'e dlia vseh - Vse dlia zdorov'ia v Rossii (Seriia dokladov po politike v oblasti ohrany zdorov'ia naseleniia). - 2000. - No. 6. - P. 119-122

8. Arsenieva, L. Yu. Dosvid i perspektyvy zbahachennia khliba yodom [Text] / L. Yu. Arsenieva, L. O. Herasymenko, M. M. Antoniuk // Problemy kharchuvannia. - 2004. - No. 1. - P. 35-43.

9. Britov, A. N. Protivorechiia i puti resheniia federal'nih tselevyh programm profilaktiki defitsita ioda i arterial'noi gipertoni [Text] / A. N. Britov, A. F. Tsyb, R. G. Oganov et al. // Materialy mezhdunarodnoi nauchnoi konferentsii «Sotsial'nomeditsinskie aspekty sostoianiia zdorov'ia i sredy obitaniia naseleniia, prozhivaiushchego $\mathrm{v}$ ioddefitsitnyh regionah Rossii i stran SNG». - Tver', 2003. - P. 33-36.

10. Delange, F. Optimal Iodine Nutrition during Pregnancy, Lactation and the Neonatal Period [Text] / F. Delange // International Journal of Endocrinology and Metabolism. - 2004. No. 2. - P. 1-12

11. Korzun, V. N. Ekoloho-hihiienichni problemy kharchuvannia naselennia pivnichnykh rehioniv Ukrainy [Text] / V. N. Korzun, I. P. Los, P. V. Zamostian et al. // Hihiiena naselenykh mists. - 2003. - Vol. 42. - P. 442-448.
12. Beliaeva, N. A. Pishchevaia dobavka iod-aktiv v profilaktike i lechenii endemicheskogo zoba [Text] / N. A. Beliaeva, A. F. Tsyb, V. V. Shahtarin et al. // Materialy mezhregional'nogo seminara «Metodologiia razrabotki i realizatsii regional'nyh programm «Zdorovoe pitanie»». - Tver', 2001. - P. 110-113.

13. Egushova, E. A. Razrabotka i issledovanie tehnologii molochno-belkovoi pasty, obogashchennoi iodom [Text]: $\mathrm{PhD}$ thesis: 05.18 .04 / E. A. Egushova. - Kemerovo, 2002. - 18 p.

14. Leskova, S. Yu. Razrabotka tehnologii iodirovannyh belkovozhirovyh emul'sii dlia proizvodstva varenyh kolbas [Text]: $\mathrm{PhD}$ thesis: 05.18.04 / S. Yu. Leskova. - Ulan-Ude, 2005. - 120 p.

15. Boeva, A. Yu. Formirovanie uluchshennyh potrebitel'skih svoistv kulinarnyh izdelii na osnove morskoi kapusty putem sovershenstvovaniia ih sostava i tehnologii proizvodstva [Text]: $\mathrm{PhD}$ thesis: 05.18.15 / A. Yu. Boeva. - Moscow, 2010. - 230 p.

16. Haldimann, M. Iodine content of food groups [Text] / M. Haldimann, A. Alt, A. Blanc, K. Blondeau // Journal of Food Composition and Analysis. - 2005. - Vol. 18, No. 6. - P. 461-471. doi:10.1016/j.jfca.2004.06.003

17. Gorbatov, A. V. Strukturno-mehanicheskie harakteristiki pishchevyh produktov [Text] / A. V. Gorbatov, S. A. Machihin. Moscow: Legkaia promyshlennost', 1982. - 296 p.

18. Hartman, K. Planirovanie eksperimenta $\mathrm{v}$ issledovanii tehnologicheskih protsessov [Text] / K. Hartman, Ye. Letskii, V. Shefer. - Moscow: MIR, 1977. - 552 p.

19. Antipova, L. V. Metody issledovaniia miasa i miasnyh produktov [Text] / L. V. Antipova, I. A. Glotova, I. A. Rogov. - Moscow: Kolos, 2004. - 571 p.

20. Peresichnyi, M. Recipe optimization of vegetable pasta with iodine-containing raw material [Text] / M. Peresichnyi, K. Palamarek // Technology Audit and Production Reserves. 2016. - Vol. 2, No. 4 (28). - P. 11-17. doi:10.15587/23128372.2016 .65317

21. Vegetable paste of functional purpose [Electronic resource] Patent UA 73970 U / Bilenka I. R., Bulansha N. A., Melnyk O. S.; assignee: Odessa National Academy of Food Technologies. - Appl. No. u201204488; Filed April 9, 2012; Publ. October 10, 2012, Bull. No. 19. - Available at: \www/URL: http://uapatents.com/4-73970-ovocheva-pasta-funkcionalnogopriznachennya.html

22. Peresichnyi, M. I. Funktsionalno-tekhnolohichni vlastyvost yodovmisnoi syrovyny ta ekstraktu inaktyvovanykh drizhdzhiv [Text] / M. I. Peresichnyi, K. V. Palamarek // Visnyk Lvivskoi komertsiinoi akademii. Seriia tovaroznavcha. - 2016. Vol. 16. - P. 63-68.

\section{ИССЛЕДОВАНИЕ ГИДРАТАЦИИ И ФОРМИРОВАНИЯ СТРУКТУРНО-МЕХАНИЧЕСКИХ СВОЙСТВ ОВОЩНЫХ ЛАСТ С ЙОДСОДЕРЖАЩИМ СЫРЬЕМ}

Экспериментально обосновано технологические свойства и структурно-механические характеристики овощных паст при различных гидромодулях обводнения порошков гидробионтов и ламинарии. Исследовано влияние продолжительности набухания порошков гидробионтов и ламинарии на свойства паст. Обосновано влияние концентрации гидратированных порошков ламинарии и гидробионтов на структурно-механические показатели овощных паст. Определены рациональные содержания гидратированных порошков из ламинарии и гидробионтов.

Ключевые слова: структурно-механические характеристики, овощные пасты, порошки гидробионтов и ламинарии, йодсодержащее сырье.

Palamarek Karina, PhD, Assistant Professor, Department of Technology and Restaurant Business, Chernivtsi Trade and Economic Institute of the Kyiv National Trade and Economics University, Chernivtsi, Ukraine, ORCID: http://orcid.org/0000-0003-4138-404X 